46. GEOLOGICAL SETTING OF SITE 372

\title{
46.1. GEOLOGICAL AND GEOPHYSICAL SETTING OF DSDP SITE 372 (WESTERN MEDITERRANEAN)
}

\author{
A. Mauffret, L. Montadert, M. Lavergne, and C. Willm, Institut Français du Pétrole \\ 92502 Rueil Malmaison, France
}

\section{INTRODUCTION}

Two surveys were carried out by I.F.P.-C.N.E.X.O. north and west of Menorca Island in preparation for Leg 42A. These two surveys enable us to interpret the results of Site 372 within a precise geological framework.

\section{Geological Framework}

Site 372, east of Menorca, is in a transitional area between the Balearic-Provencal Abyssal Plain, the Gulf of Valencia, and the Balearic Rise. Mallorca and Ibiza islands belong to the Betic belt which was highly tectonized during the middle Miocene (Apostolescu et al., 1974; Bizon et al., this volume; Biju-Duval et al., this volume). The Gulf of Valencia and Menorca (?) belong to the foreland which was hardly affected by this Miocene orogeny. The recovery of undisturbed Burdigalian deposits just east of Menorca (Site 372) supports this conclusion. We may thus, with some confidence, compare the geology of the eastern margin of Menorca with the Gulf of Valencia. The ages of the Gulf of Valencia and the Balearic-Provencal Basin are probably similar (Oliogocene to early Miocene) (Le Pichon et al., 1971), and the two early opening stages (thermal swelling and rifting) can be recognized in both areas.

\section{Thermal Swelling}

Oil industry data (Stoeckinger, 1976) show that the Miocene sediments lie directly on Mesozoic sediments on the northwest continental shelf of the Gulf of Valencia, whereas towards the center of the Gulf, the Mesozoic rocks disappear and the basement is mainly Paleozoic rocks.

On the other side of the Balearic margin Paleozoic rocks were dredged (Bourrouilh and Mauffret, 1975).

On the Balearic Islands, the Mesozoic is exposed locally. During the Oliogocene, Mesozoic clastic sediments were trapped in grabens (Stoeckinger, 1976) and continental deposits and evaporites are known from the Ebro Basin. The lack of Mesozoic rocks in the center of the Gulf may have been caused by erosion linked to this thermal swelling.

\section{Rifting}

During and after the thermal swelling, rifting occurred, resulting in the creation of horst and graben structures.

The rifting in the eastern part of the Gulf of Valencia is marked by the formation of such features along the Catalonia Margin (Figure 1). The rifting was probably also responsible for the creation of the Valles Penedes graben in Spain. The Mallorca continental margin is bounded on the northeast by a significant northwest-southeast trending fault. Prolongations of this feature are seen also between Menorca and Mallorca and on the Catalonia Margin itself. On land in the region of Barcelona, a dextral strike-slip fault may also be related to this feature. The fault may be a transform fault linked to a displacement of Menorca.

In the Oliogocene, the late-Hercynian conjugate fault systems (northeast-southwest and northwestsoutheast trends) were probably reactivated. These structural trends have been active during the Miocene and Pliocene-Quaternary and are related to the opening and subsidence of the deep western Mediterranean basins.

The acoustic basement, as recorded in the area between the Catalonia Margin and Menorca, is correlated with the volcanic layer drilled in DSDP Hole 123 (ash and volcanic glass dated at $20 \pm 2$ m.y.B.P.; Ryan, Hsü, et al., 1973).

North of Menorca, a large magnetic anomaly has been interpreted as evidence of another fracture zone, and the Cenozoic volcanoes present in the area may also be related to this feature. On the "Spartacus Seamount" (Figure 1), olivine basalt has been dredged (Bellaiche et al., 1974). The submarine volcanoes associated with Columbretes Island are the superficial manifestation of a deep linear fracture (Galdeano and Rossignol, in press).

Volcanic rocks were emplaced in the attenuated continental crust between the islands of Mallorca and Ibiza and the Valencia Margin (Hinz, 1972).

The Gulf of Valencia was probably formed at the same time as the deep Balearic-Provencal Basin (Oligocene to early Miocene), and this aborted rift with a thin continental crust, is probably linked either to the drift of the Corsica-Sardinia block or to the opening of the North Algerian Basin (Biju-Duval et al., this 


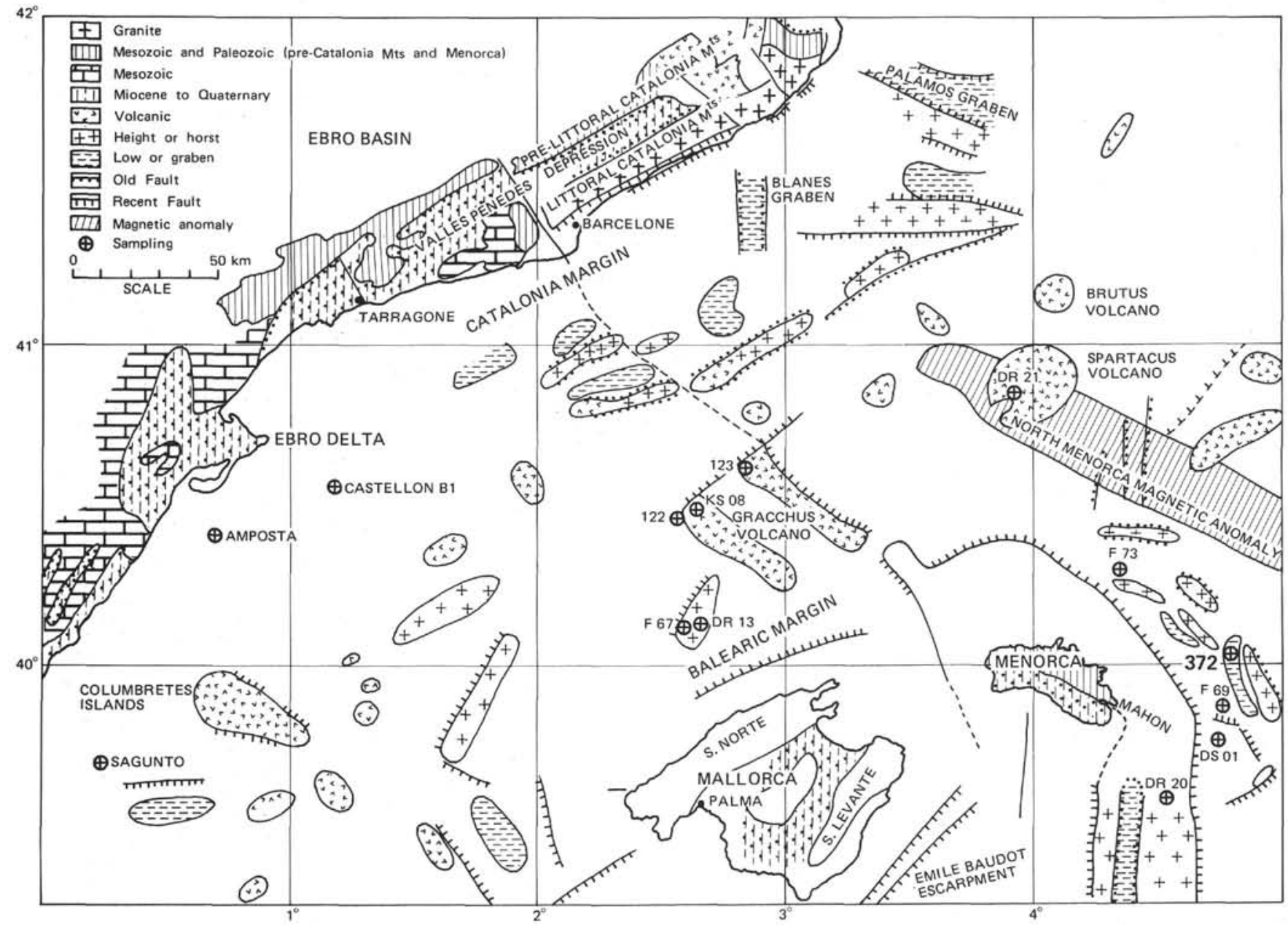

Figure 1. Structural map of the Gulf of Valencia and adjacent areas.

volume). However, the geological evolution of the Gulf of Valencia did not stop during Miocene time. Continuous volcanic activity, particularly marked during Messinian and early Pliocene times, occurred up to the present (Mauffret, 1976).

\section{ANALYSIS OF THE GEOLOGICAL AND GEOPHYSICAL SETTING OF SITE 372}

\section{Structures}

Some of the tectonic events responsible for the creation of the Balearic-Provencal Basin and the Gulf of Valencia are recognized along the eastern and northern margin of Menorca.

On the northern margin an east-west trend is linked to the rifting of the Gulf of Valencia. The eastern margin contains several northwest-southeast trending horst and graben structures (Figure 2) which are probably related to the opening of the Balearic-Provencal Basin. Several of the grabens are more than 2000 meters deep. Thus there is good evidence for large-scale rifting in the area east of Menorca. Clearly, as previously indicated, these structures have been active up to the present time. Also note that the continental slope is parallel to these structural features.

\section{Sedimentary Cover}

One profile, J 211 (Figure 3), shows two distinct depressions filled by a lower, probably clastic unit. The same unit also fills the half graben illustrated in profile J 212 (Figure 4). This series lies on the relief of the acoustic basement and is directly succeeded by upper Burdigalian deposits. These were not reached by Hole 372 , but they probably are Oligocene continental sediments as occur in the Gulf of Valencia. We also suspect that evaporites are present, as indicated by the nigh-salinity interstitial water measured at the bottom of Hole 372 (Site 372 Report, this volume). Such a hypothesis is supported by the presence of evaporites in the sediments just below the Miocene deposits of the Valles Penedes graben (Anonymous, 1963). Upper Miocene continental sediments were described in DSDP Hole 133 (Figure 5) on the western Sardinia margin (Ryan, Hsü, et al., 1973). It now seems likely, from a re-examination of seismic data, that these series are lower Miocene to Oligocene and were deposited during rifting of the margin.

Site 372 reached lower Burdigalian sediments (Profile J 204, Site 372 Report, this volume) characterized by a transparent acoustic layer. The calculated sedi- 
mentation rate was very high and is probably linked to the creation of a new topography in Aquitanian times.

The upper Burdigalian to Tortonian series is thinner. It is represented in Profile J 212 (Figure 4) as a wellstratified acoustic unit covering all the other units. This large-scale transgressive unit is also known on land (Balearic Islands and Iberian Peninsula). The emergent land areas were consderably eroded during early Burdigalian time, then partially submerged during late Burdigalian time. Thus, the sedimentation rate was reduced. The acoustic unit may represent the same deposit as that existing below the salt layer in the abyssal plain.

On the Menorca continental rise this unit (I) is irregularly covered by thin sedimentary accumulations (Profile J 204, Site 372 report, this volume). Messinian marine sediments have been cored on one of these features (Bizon et al., 1975; Bizon et al., this volume).

We also noted a large erosional surface (Montadert et al., this volume), just on top of the well-stratified unit, which can be followed basinward until the appearance of the salt layer. More than 500 meters of upper Burdigalian to Messinian deposits have been eroded and the upper evaporites may lie directly on top of the acoustic basement (Profile J 203, Figure 6). Locally the acoustic basement may also have been eroded (Profile J 211, Figure 3). We believe that this important erosional event must have occurred on emergent land. Thus the erosional episode may have been even greater than that which appears on Profile $\mathbf{J}$ 204 or from the results of Site 372 where marine Messinian and upper Tortonian are missing. We should note in this respect that the Messinian and Tortonian on Menorca are represented by a shallow-water carbonate facies (Bizon et al., 1973) and that the same late Miocene erosional surface is present there (Bourrouilh, 1973).

The abyssal plain salt series is discussed elsewhere in this volume (Montadert et al.). We note here, however, that the evaporites lay at an average depth of

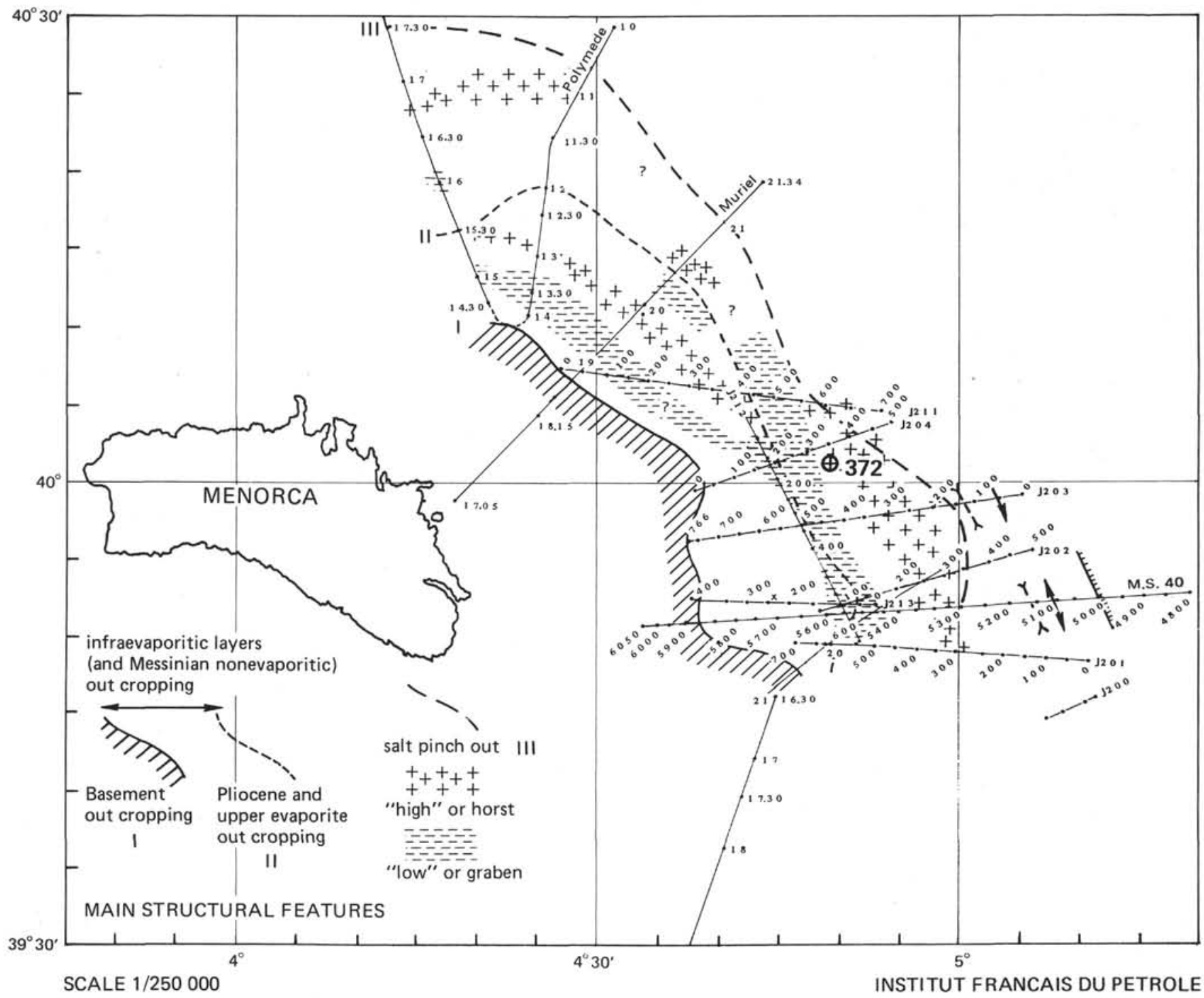

Figure 2. Detailed map of the Site 372 area. 

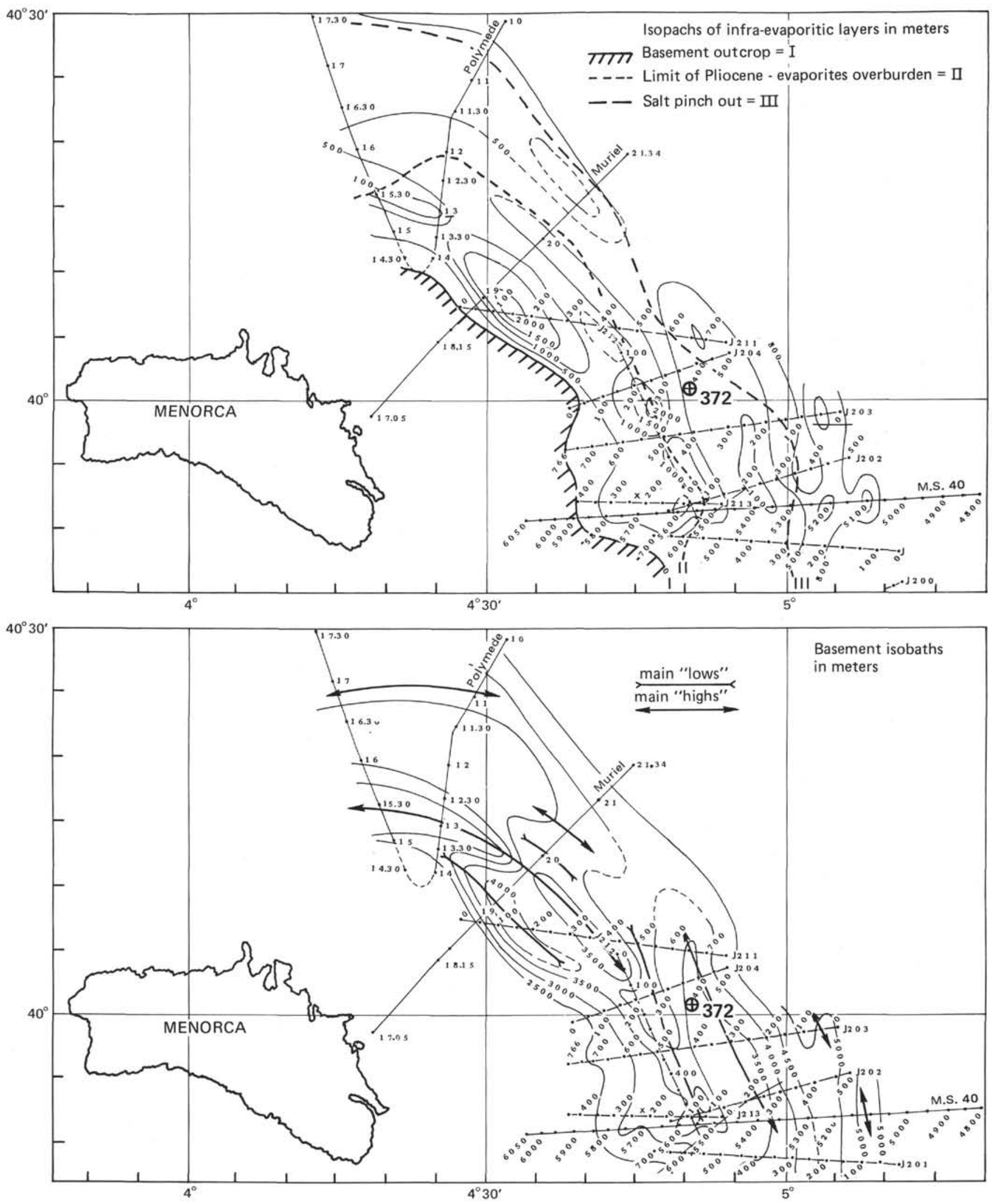

Figure 2. (Continued). 


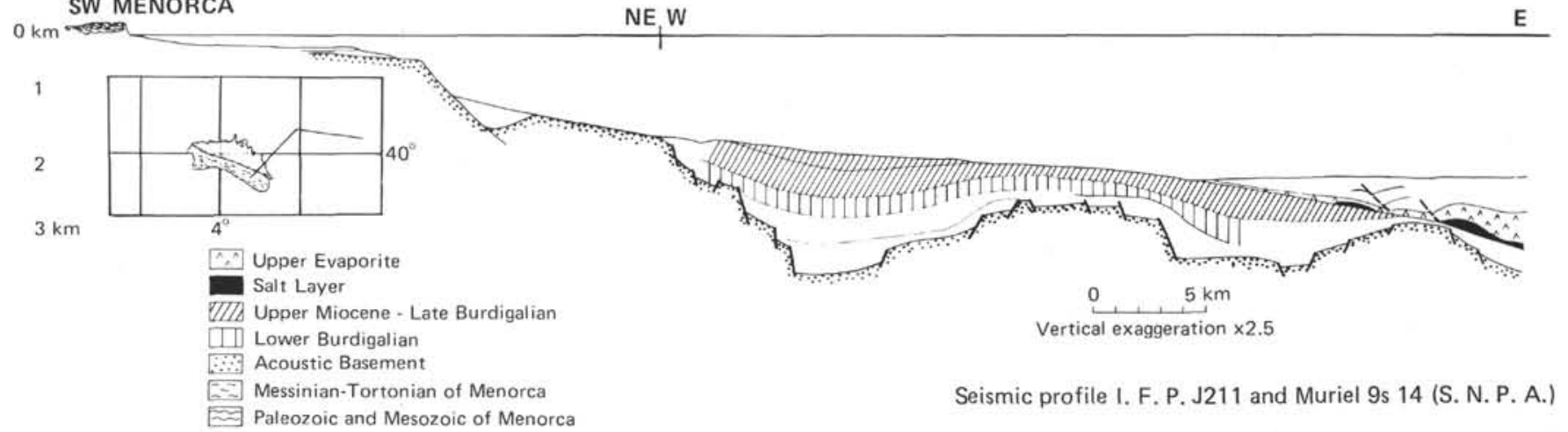

Figure 3. Cross-section from Menorca to the abyssal plain.

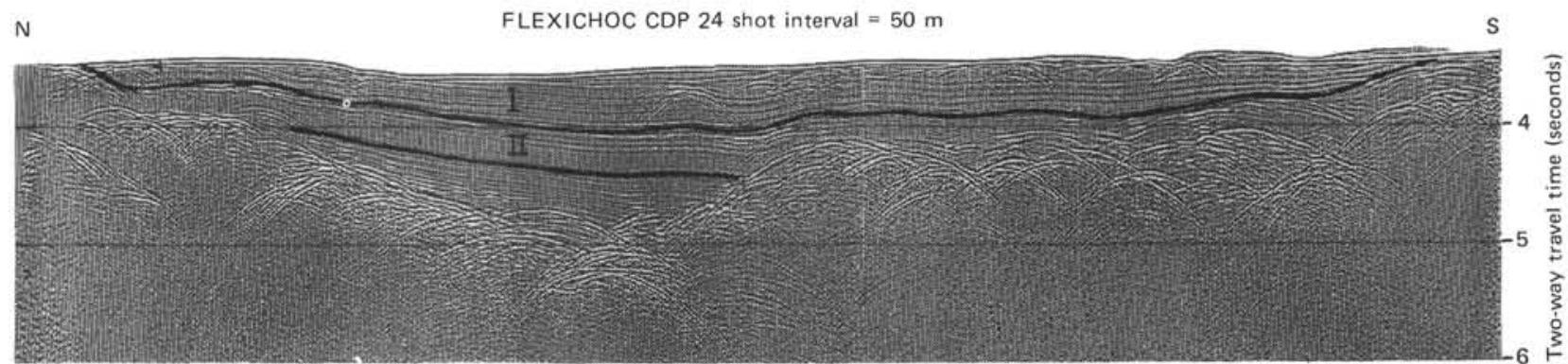

I Upper Burdigalian to Messinian

II Lower Burdigalian

$5 \mathrm{~km}$

DEPTH SECTION interval velocities in meters/sec.

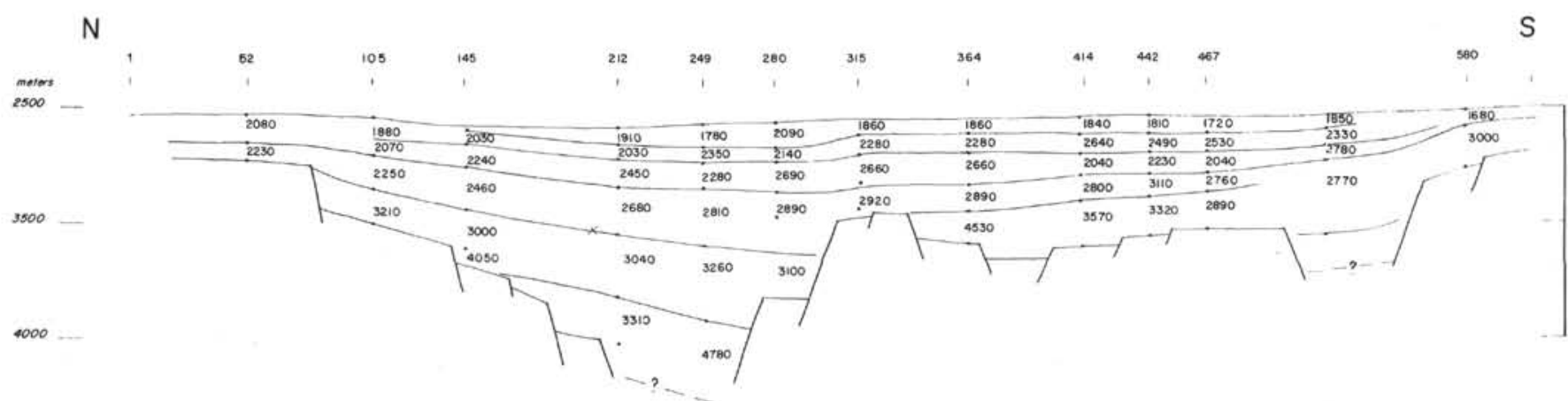

Figure 4. Seismic profile J212 and geological correlations.

2700 meters, which may be a result of a PlioceneQuaternary subsidence brought about by cooling and isostatic loading of an already deep Miocene basin.

The Pliocene to Pleistocene sediment sequence shows evidence of

1) slumping and sliding, visible where the salt layer pinches out. Such features are frequently detected on profiles over the western Mediterranean basin.

2) bottom currents; for example at the foot of the north slope of Menorca where a linear depression (about $300 \mathrm{~m}$ deep) is bounded on the abyssal plain side by a sedimentary ridge. Also east of Menorca in an area sheltered from the Ebro sedimentary supply, contour currents are thought to be responsible for exposure of the infrasalt series.

\section{COMPARISON OF SEISMIC VELOCITIES (MEASURED BY SEISMIC PROFILING) WITH SONIC VELOCITIES (MEASURED IN CORES)}

Velocities obtained by pseudo-log analysis, such as those from the Flexichoc seismic profile J 211, have been compared with measurements of sonic velocity made independently on core samples from Site 372. 


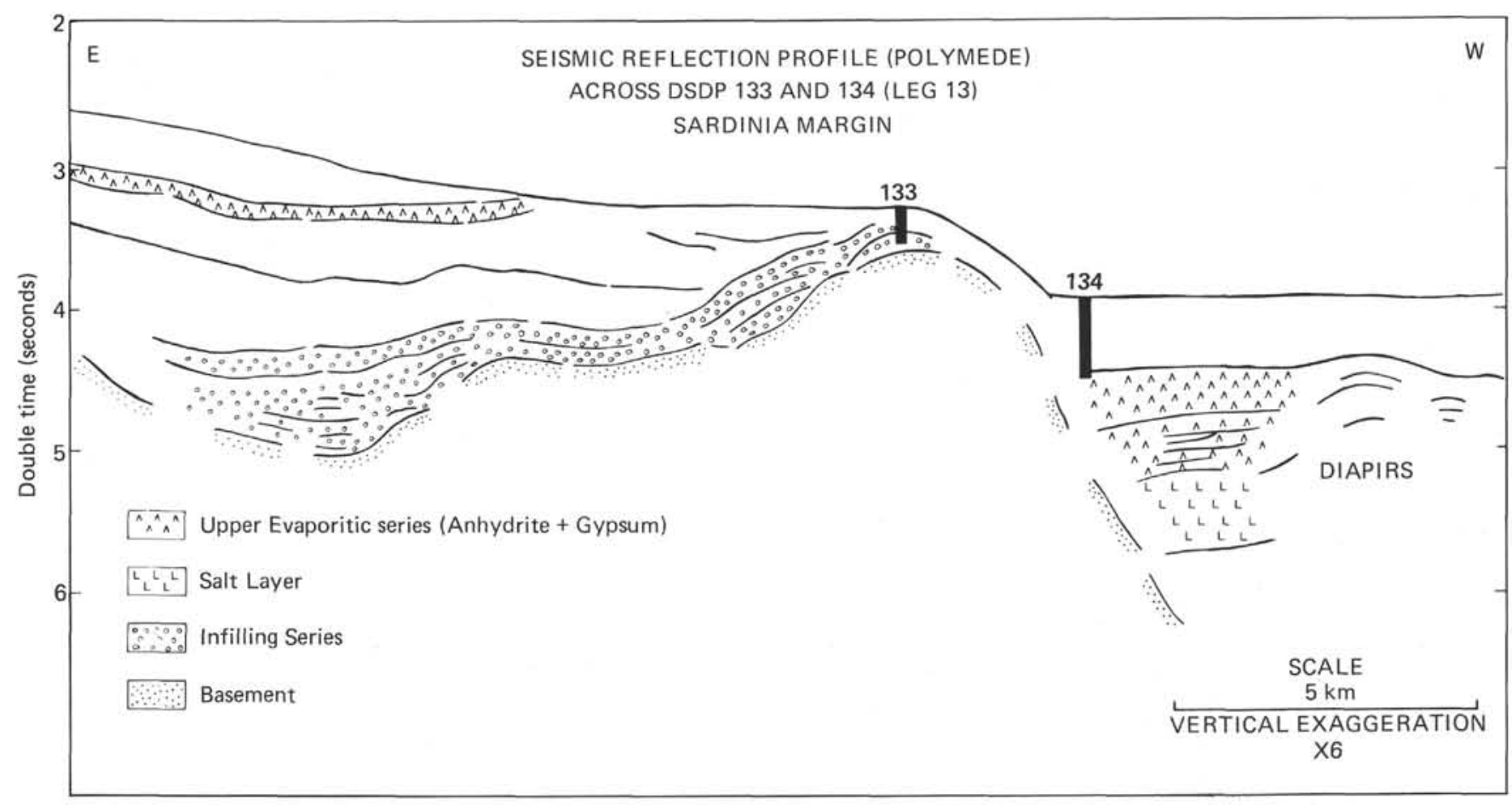

Figure 5. Re-examination of the seismic profile off the Sardinia margin in relation to DSDP Sites 133 and 134.

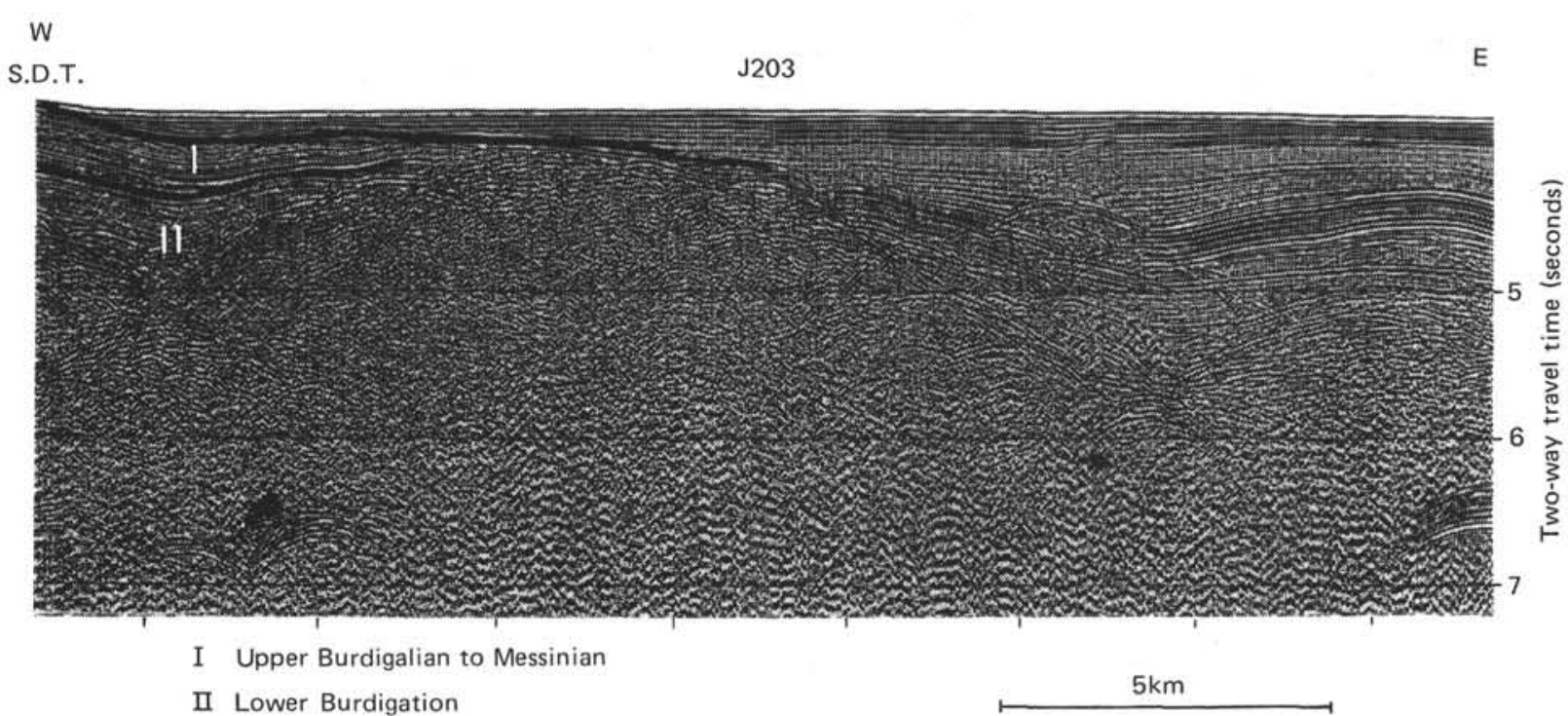

Figure 6. The upper Burdigalian to Messinian series cut by a large erosional surface in Profile J203.

The 171 shot from seismic profile J 211 (Figure 7) was used for pseudo-velocity log analysis. It was taken in water depths of $15 \mathrm{~km}$ east of Menorca and about 5 $\mathrm{km}$ northwest of Site 372. Seismic profile J 204, which crosses directly over the drill site, was not used for technical reasons. Seismic correlation between the 171 shot and Site 372 areas show equivalent seismic units at 200 to 800 meters, but no such correlation exists for the upper unit $(0-200 \mathrm{~m})$.

Pseudo-velocity logs (Figures $8 \mathrm{a}$ and $8 \mathrm{~b}$ ) were computed from multichannel seismic data, using the
RMS velocity analysis and true reflection amplitude (Lavergne and Willm, in press). We see

1) a rapid increase in velocity from $1800 \mathrm{~m} / \mathrm{sec}$ to $2400 \mathrm{~m} / \mathrm{sec}$ within the Burdigalian series between 400 and 600 meters depth.

2) a relatively constant velocity, around 2400 $\mathrm{m} / \mathrm{sec}$, between 600 and 885 meters depth.

The drilling was terminated at a depth of 885 meters subbottom. The velocity curves between 0 and 885 meters are comparable (Figure 9). We note particularly the rapid increase at the top of the Burdigalian. 


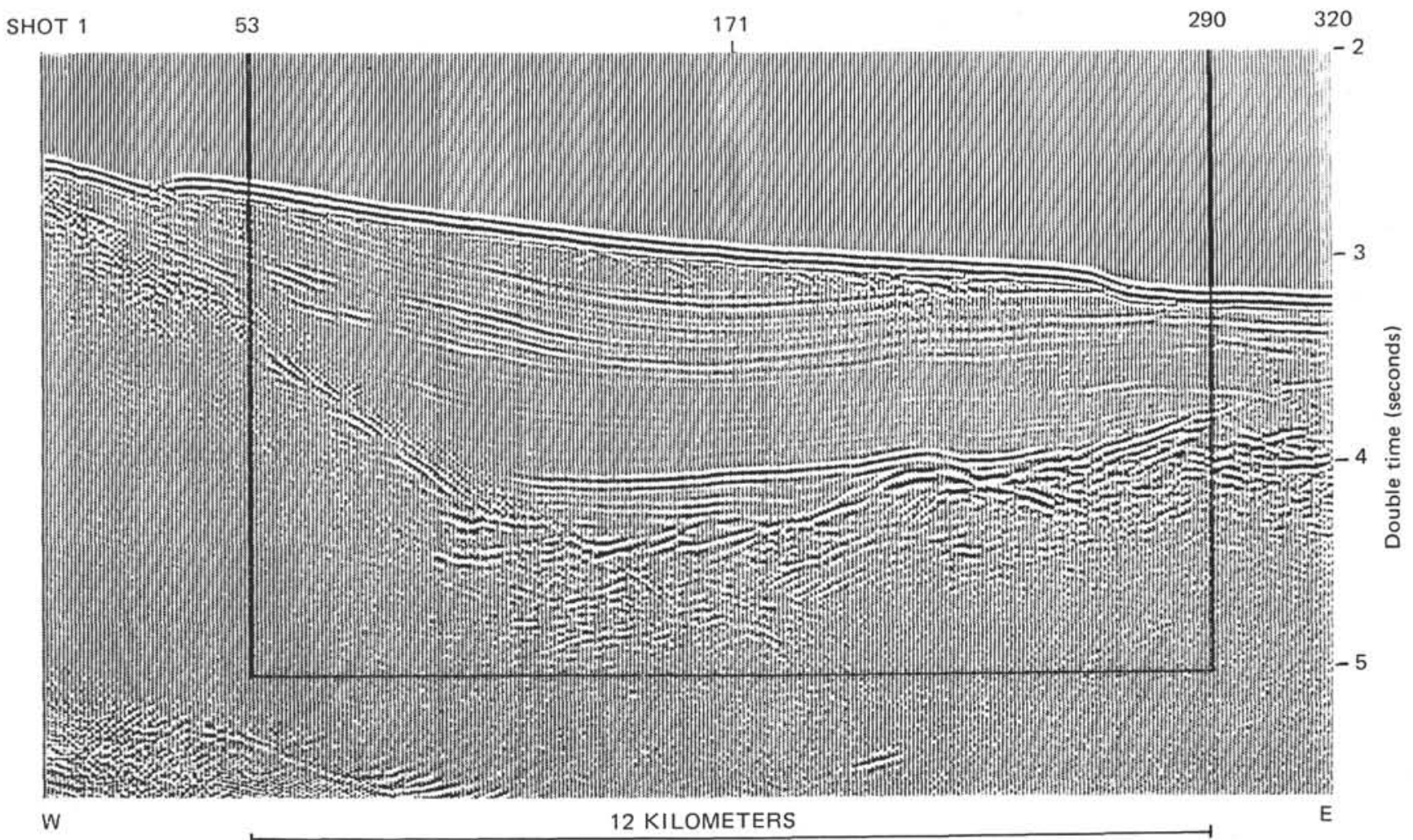

Figure 7. Migrated seismic profile J211. Shots 1 to 320.

Although the two velocity curves are comparable, the measured ultrasonic values are always systematically lower than the computed pseudo-velocity log values. The ratio of core velocity to seismic velocity varies between 0.8 and 0.9 . This is probably because the shipboard velocity measurements are made at ambient atmospheric pressure. At depth, the temperature and pressure conditions are obviously different. Thus, the data are compatible.

Between 1500 to 2000 meters, the relatively high velocities might be caused by the presence of Aquitano-Oligocene sandstones and evaporites.

\section{CONCLUSIONS}

Hole 372 and its accompanying site survey provide very useful information about the structural and sedimentary history of the western Mediterranean Sea.

Following a thermal swelling during the upper Eocene to Oligocene, horst and graben structures were created in the area by distension. The North Mediterranean Basin probably opened and drifted apart during the Aquitanian, with rapid infilling of a deep basin by detrital sediments and continued until the lower Burdigalian. The upper Burdigalian to Tortonian is marked by a large-scale transgression. After the Messinian evaporitic event, the basin was modified to its present shape by subsidence.

Good correlation is evident between the two velocity determination techniques, and thus geological data from Hole 372 can be extrapolated to the seismic sections.
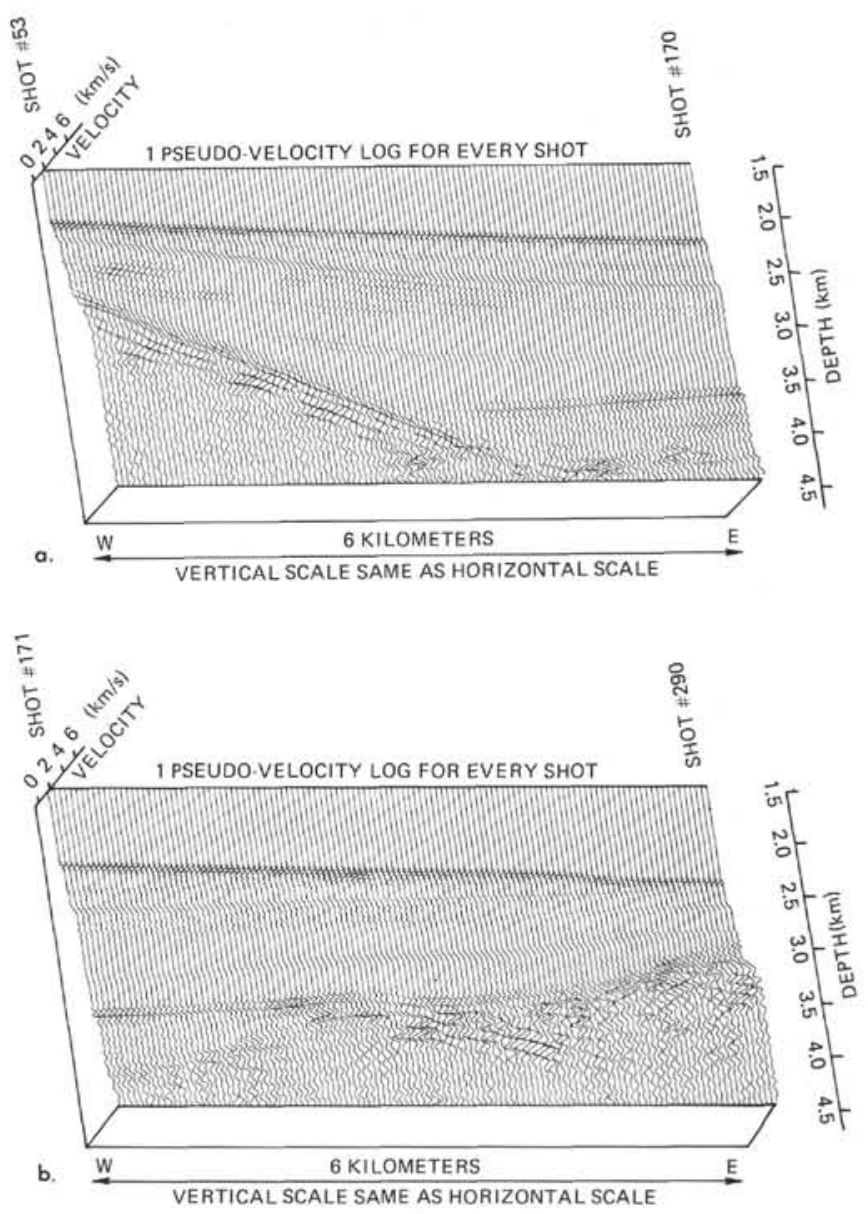

Figure 8. Pseudo-velocity section computed from seismic data along profile J211 (a) Shots 53 to 170 and (b) 171 to 290. 


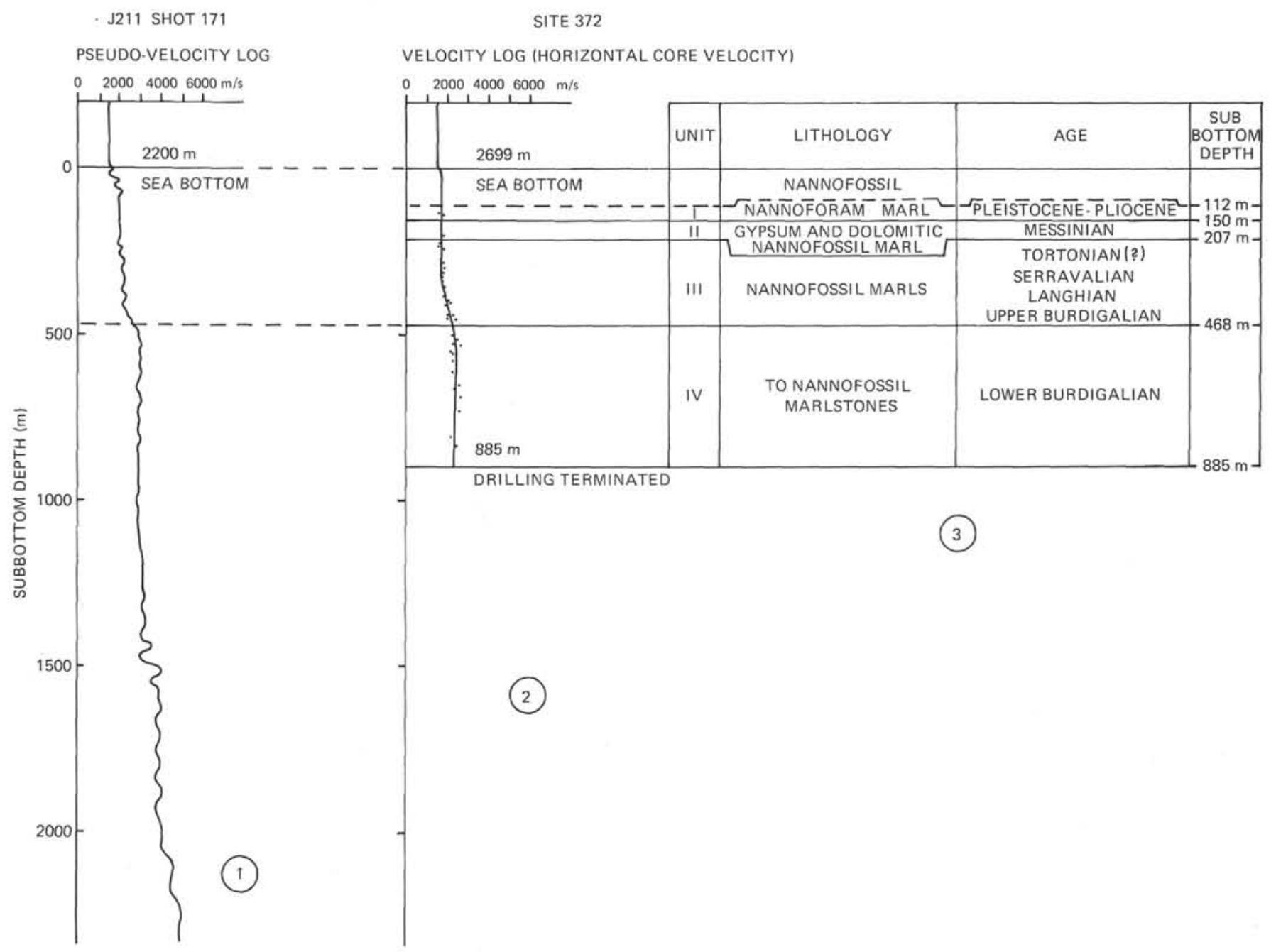

Figure 9. Comparison of seismic velocities, computed by pseudo-velocity log analysis, with sonic velocities, measured on core samples, and Lithological/units correlation. 1. Pseudo-velocity log of Shot 171 from seismic profile J211. 2. Velocity log measured using an ultrasonic technique on core samples from Hole 372. 3. Stratigraphy of Site 372.

\section{ACKNOWLEDGMENTS}

We are gratefull to $\mathbf{J}$. Letouzey, M. Gennesseaux, and $\mathbf{J}$. Mascle for critical reviews and discussion of this contribution. We particularly thank J. Mascle for his help with the English version.

\section{REFERENCES}

Anonymous, 1973. Mapa geologico de Espana, 1/50.000: Villa franca del Panades.

Apostolescu, V., Biju-Duval, B., Bizon, G., Courrier, P. Letouzey, J. and Mauffret, A., 1974. Le problème du Miocène inférieur et moyen des cordillères bétiques en Espagne continentale et dans les iles Baléares: 2ème Reun. Ann. Sci. Terre, Nancy, p. 11.

Auzende, J. M., Bonnin, J., and Olivet, J. L., 1973. The origin of the Western Mediterranean Basin: J. Geol. Soc. London, v. 129 , p. 607-620.

Bellaiche, G., Gennesseaux, M., Mauffret, A., and Rehault, J. P., 1974. Prèvements systématiques et caractérisation des réflecteurs acoustiques: nouvelle étape dans la compréhension de la geologie de la Mediterranee occidentale Marine Geol., no. 16, M 47-M 56.
Bizon, G., Bizon, J. J., and Mauffret, A., 1975. Présence du Miocène terminal et de Pliocène inférieur au large de Minorque (Baléares, Espagne): Rev. Inst. Fr. du Pétr., v. 30 , p. 713-723.

Bizon, G., Bizon, J. J., Bourrouilh, R., and Massa, D., 1973. Présence aux iles Baléares (Méditerranée occidentale) de sédiments "messiniens" déposés dans un mer ouverte à salinité normale. C.R. Acad. Sci., v. 277, p. 985-988.

Bourrouilh, R., 1973. Stratigraphie, sédimentologie et tectonique de l'ile de Minorque et du Nord-Est de Majorque (Baléares) - La terminaison nord-orientale des cordillères bétiques en Méditerranée: Thesis.

Bourrouilh, R. and Mauffret, A., 1975. Le socle immergé des Baléares (Espagne). Données nouvelles apportées par des prélèvements sous-marins: Bull. Soc. Géol. France, v. 7, p. 1126-1130.

Galdeano, A. and Rossignol J. C., in press. Etude aéromagnétique du golfe de Valence: Earth Planet. Sci. Lett.

Hinz, K., 1972. Results of Seismic Refraction Investigations (Project Anna) in the Western Mediterranean Sea, South and North of the Island of Mallorca: Bull. Centr. Rech. Pau, v. 6, p. 405-406.

Lavergne, M. and Willm, C., in press. Inversion of Seismograms and Pseudo Velocity Logs: E.A.G. Mtg, Bergen 1975 ( to be published in Geophys.Prospect.) 
Le Pichon, X., Pautot, G., Auzende, J. M., and Olivet, J. L., 1971. La Méditerranée occidentale depuis l'Oligocène. Schéma d'evolution: Earth Planet. Sci. Lett., v. 13, p. 145152.

Mauffret, A., 1976. Etude géodyamique de la marge des iles Baléares.
Ryan, W. F. B., Hsü, K. J., et al., 1973. Initial Reports of the Deep Sea Drilling Project, Volume 13: Washington (U. S. Government Printing Office).

Stoeckinger, W. T., 1976. Valencia Gulf. Offer Deadline nears: Oil Gas J., March, p. 197-204; April, p. 181-183.

\title{
46.2. COMPARISON BETWEEN FORMATIONS DRILLED AT DSDP SITE 372 IN THE WESTERN MEDITERRANEAN AND EXPOSED SERIES OF LAND
}

\author{
G. Bizon and J. J. Bizon, Bureau d'Etudes Industrielles et Coopération de l'Institute Français du Pétrole, 92500 \\ Rueil Malmaison, France \\ and \\ B. Biju-Duval, Institut Français du Pétrole, 92500 Rueill-Malmaison
}

\begin{abstract}
Formations penetrated at Site 372 are compared with series cropping out on land in the Balearic Islands, Southern Spain, and Sardinia. The comparison is extended to wells drilled in the Gulf of Lion. The margin at Menorca and the North Balearic Provençal Basin appear to be at least of Burdigalian age. The entire Miocene is undisturbed at Site 372 in contrast to Mallorca and continental Spain where important tectonic events occurred during middle and upper Miocene.
\end{abstract}

\section{INTRODUCTION}

Because DSDP Site 372 is located only $40 \mathrm{~km}$ from the Balearic Islands, it is logical to compare the series penetrated at the site with land equivalents, particularly with those on the island of Menorca. As will be demonstrated below, time-equivalent series on the Balearic Islands are characterized by a shelf facies and do not correspond to the pelagic marls penetrated in the Hole 372. The comparison will be extended to the wells drilled by the Compagnie Françise des Pétroles in the Gulf of Lion, and then to Sardinia and southern Spain. Finally, the study of a 3-meter core taken southwest of Site 372 will complete our interpretation.

\section{Comparison with Menorca Island}

Burrouilh (1973) demonstrated that the island of Menorca can be divided into two geological provinces, a tectonically disturbed northern and northeastern region, the "Tramuntana," and a platform area to the south-southwest, consisting of post-tectonic molasses, the "Mindjorn.",

In the former area, the oldest outcrops range in age from Devonian to Keuper. The Keuper is unconformably overlain by lacustrine conglomerates, the cement of which contains charophytes indicating a late Oligocene to early Miocene age. Reworked components of the conglomerate are from Jurassic to late Aptian age.
By comparing these rocks with those of Mallorca, Bourrouilh considered the age of tectonism to be middle Miocene. This conclusion is questionable considering that at Site 372 the entire Miocene is undisturbed.

In the latter area (Figure 1A) the series is undisturbed except for recent faulting. The sediments are a chalky facies, cropping out in the south-southwestern part of the island. The carbonate formations are often rich in algae; echinoderms, pectens, and, locally, corals are also present. The foraminifers are esentially benthic with outer shelf (Amphistegina, Heterostegina) and inner shelf genera (Borelis). This shallow water facies was determined by Bourrouilh and Colom (1968) to be middle Miocene (Vindobonian) in age. In the southern part of the island near San Thomas, some planktonic foraminifer assemblages (Globorotalia humerosa Zone, Bizon et al., 1973) indicate that late Miocene sediments are present. Beyond the outcrops just mentioned, the Vindobonian molasses are, in fact, rather poorly dated, but are generally thought to range in age from Langhian to Tortonian.

To the southeast of Menorca, on Rey Island, at the contact between the tectonically disturbed and posttectonic series and at the base of the Vindobonian molasses (Bourrouilh, 1973, p. 467), Miogypsina (sp. undet.) has been found in a dolomitic facies. Their presence, if they occur in situ (and there is no evidence 